\title{
Genetic difference in HLA-DR phenotypes between coeliac disease and transitory gluten intolerance
}

\author{
R Meuli, W J Pichler, H Gaze, M J Lentze
}

\begin{abstract}
Genetic differences in HLA phenotypes were studied in coeliac disease to investigate why some patients do not react with mucosal damage after gluten challenge. Forty five children with coeliac disease and 16 with transitory gluten intolerance were typed; 76 subjects served as controls. HLA phenotypes in children with coeliac disease had significantly higher proportions of DR3/X and DR5/7 than controls $(48.8 \% \quad v \quad 11 \cdot 8 \%$ and $26 \cdot 7 \%$ v $5 \cdot 3 \%)$. Children with transitory gluten intolerance had lower DR3/X (43.8\%) than children with coeliac disease and there were no DR5/7 phenotypes.

Further analysis of similarly well defined cases might show whether genetic differences in the $D R 3 / X$ and DR5/7 phenotypes can serve as a marker for the permanence of gluten intolerance. (Arch Dis Child 1995; 72: 29-32)
\end{abstract}

Keywords: HLA-DR phenotypes, coeliac disease, transitory gluten intolerance.

Coeliac disease has been recognised since 1888 when Samuel Gee first described the 'coeliac affection' as a disease entity with severe malabsorption and chronic diarrhoea combined with failure to thrive. ${ }^{1}$ The typical hyperplastic villous atrophy of the proximal small intestine as a reaction to the toxic agent gluten $^{2}$ is considered to be mediated initially by an immunological reaction of the $\mathrm{T}$ lymphocytes of the mucosal lamina propria. These are predominantly of the CD4+ type. ${ }^{3}$ Genetic control of this reaction is related to the major histocompatibility complex (MHC) region of chromosome 6 , which encodes the MHC class I and class II molecules. ${ }^{4}$ In this way coeliac disease affects genetically susceptible individuals. Susceptibility to coeliac disease has also been associated with HLAA8, ${ }^{67}$ HLA-DR, ${ }^{8-11}$ and HLA-DQ ${ }^{12} 13$ class antigens. In children with coeliac disease the permanence of the disease, according to the original European Society for Paediatric Gastroenterology and Nutrition (ESPGAN) criteria, ${ }^{14}$ was demonstrated by gluten challenge after an initially flat mucosa, good recovery with a gluten-free diet, and morphological normalisation of the mucosa after following the diet for at least two years. Some patients did not react clinically and/or morphologically after gluten challenge according to these criteria, which led to the concept of transitory gluten intolerance. ${ }^{15}$ It remains unclear whether genetic differences in the MHC class II molecules on the short arm of chromosome 6 could be responsible for this condition. Production of antigliadin antibodies of the IgG class and IgA class as well as antiendomysial antibodies have been shown to correlate with the immune response to gliadin. ${ }^{16-19}$ In the mouse, two separate genetic loci on chromosomes 12 and 17 control the immune response to gliadin. ${ }^{12}$ This study was performed to investigate whether there are genetic differences in the HLA-DR class antigens in children with coeliac disease and those with transitory gluten intolerance.

\section{Patients and methods}

PATIENTS

Two groups of patients, 20 boys and 41 girls, unrelated and aged 8 to 22 years were studied. Group I consisted of 21 patients in whom the diagnosis of coeliac disease was made by the typical clinical picture at presentation without initial biopsy, followed by a gluten-free diet for at least two years and good clinical recovery, then subsequent gluten challenge with histological reaction after having an intestinal biopsy. They were considered to have permanent coeliac disease. In the 40 subjects of group II, the diagnosis of coeliac disease was based on the original ESPGAN criteria. After the establishment of the diagnosis, shown by clinical presentation and hyperplastic villous atrophy in the first biopsy, the patients recovered taking a glutenfree diet for a minimum of two years and a second biopsy was performed before a prospective gluten challenge. All patients with coeliac disease are part of a large number of patients $(n>450)$ being followed up in the hospital.

\section{GLUTEN CHALLENGE}

A third biopsy was performed after an initial standardised gluten challenge in all patients by giving $0.5 \mathrm{~g} / \mathrm{kg}$ of body weight/day of gluten in the form of a powder added to the otherwise gluten-free diet for one month. Patients with a morphologically normal mucosa were changed to a normal diet. All patients with a histologically normal mucosa of group II $(16 / 40)$ were consecutively changed to a normal diet. They remained on a normal diet for 5-15 years. Control biopsies were performed every two years during the 
Table 1 HLA-DR antigen frequency distribution in 45 Swiss children with coeliac disease and 529 Swiss controls

\begin{tabular}{lcclc}
\hline $\begin{array}{l}\text { HLA-DR } \\
\text { antigens }\end{array}$ & $\begin{array}{l}\text { No(\%) } \\
\text { coeliac patients } \\
(n=45)\end{array}$ & $\begin{array}{l}\text { No(\%) } \\
\text { Swiss controls } \\
(n=529)\end{array}$ & $\begin{array}{l}\text { Significance } \\
(p \text { values) }\end{array}$ & $\begin{array}{l}\text { Relative } \\
\text { risk } \dagger\end{array}$ \\
\hline DR1 & $4(8 \cdot 9)$ & $101(19 \cdot 1)$ & NS & $0 \cdot 46$ \\
DR2 & $2(4 \cdot 4)$ & $150(28 \cdot 8)$ & $<0 \cdot 023$ & $0 \cdot 14$ \\
DR3 & $27(60 \cdot 0)$ & $131(27 \cdot 8)$ & $<0 \cdot 001$ & $4 \cdot 05$ \\
DR4 & $4(8 \cdot 9)$ & $148(28 \cdot 0)$ & NS & $0 \cdot 28$ \\
DR5+DR11 & $18(39 \cdot 9)$ & $139(26 \cdot 3)$ & NS & $1 \cdot 88$ \\
DR6 & $4(8 \cdot 9)$ & $108(20 \cdot 6)$ & NS & $0 \cdot 42$ \\
DR7 & $26(57 \cdot 7)$ & $116(21 \cdot 9)$ & $<0 \cdot 0001$ & $4 \cdot 82$ \\
DR8 & 0 & $30(5 \cdot 7)$ & NS & $0 \cdot 18$ \\
DR9 & $1(2 \cdot 2)$ & $11(2 \cdot 1)$ & NS & $1 \cdot 52$ \\
DR10 & $2(4 \cdot 4)$ & $9(1 \cdot 7)$ & NS & $3 \cdot 15$ \\
DR11 & $15(33 \cdot 3)$ & $118(22 \cdot 4)$ & NS & $1 \cdot 76$ \\
\hline
\end{tabular}

*Two tailed $p$ value corrected for the number of antigens tested, calculated according to Fisher's $\chi^{2}$ test with Yates's correction. †According to Woolf, with Haldane's continuity correction. NS=not significant.

Table $2 H L A-D R$ antigen frequency distribution in 16 Swiss children with transitory gluten intolerance and 529 Swiss controls

\begin{tabular}{lllll}
\hline $\begin{array}{l}\text { HLA-DR } \\
\text { antigens }\end{array}$ & $\begin{array}{l}\text { No (\%) transitory } \\
\text { gluten intolerance } \\
(n=16)\end{array}$ & $\begin{array}{l}\text { No(\%) } \\
\text { Swiss controls } \\
(n=529)\end{array}$ & $\begin{array}{l}\text { Significance } \\
(p \text { values) }\end{array}$ & $\begin{array}{l}\text { Relative } \\
\text { risk } \dagger\end{array}$ \\
\hline DR1 & $2(12 \cdot 5)$ & $101(19 \cdot 1)$ & NS & $0 \cdot 73$ \\
DR2 & $1(6 \cdot 3)$ & $150(28 \cdot 8)$ & NS & $0 \cdot 24$ \\
DR3 & $12(75 \cdot 0)$ & $131(27 \cdot 8)$ & No.001 & $8 \cdot 42$ \\
DR4 & $2(12 \cdot 6)$ & $148(28 \cdot 0)$ & NS & $0 \cdot 44$ \\
DR5+DR11 & $5(31 \cdot 3)$ & $139(26 \cdot 3)$ & NS & $1 \cdot 34$ \\
DR6 & $2(12 \cdot 6)$ & $108(20 \cdot 6)$ & NS & $0 \cdot 67$ \\
DR7 & $4(25 \cdot 1)$ & $116(21 \cdot 9)$ & NS & $1 \cdot 28$ \\
DR8 & $2(12 \cdot 5)$ & $30(5 \cdot 7)$ & NS & $1 \cdot 37$ \\
DR9 & 0 & $11(2 \cdot 1)$ & NS & $1 \cdot 66$ \\
DR10 & 0 & $9(1 \cdot 7)$ & NS & $1 \cdot 25$ \\
DR11 & $4(25 \cdot 0)$ & $118(22 \cdot 4)$ & NS & $1 \cdot 76$ \\
\hline
\end{tabular}

$\star$ Two tailed $\mathrm{p}$ value corrected for the number of antigens tested, calculated according to Fisher's $\chi^{2}$ test with Yates's correction. †According to Woolf, with Haldane's continuity correction.

NS=not significant.
(National Institutes of Health). The specificities HLA-DR 1, 2, 3, 4, 5, 11(5), 6, 7, 8, 9, and 10 could be recognised.

Statistical analysis was calculated using the two tailed Student's $t$ test corrected for the number of comparisons calculated according to Fisher's $\chi^{2}$ test with Yates's correction. Relative risks were calculated according to Woolf, with Haldane's continuity correction.

\section{Results}

The distribution of HLA-DR locus specificities in patients with coeliac disease and controls is shown in table 1 . In the group of 45 patients with coeliac disease ( 21 from group I, 24 from group II) there was a significant increase in the frequency of DR3 $(p<0.01)$ and DR7 $(p<0.01)$. In contrast DR2 was less frequent in patients with coeliac disease than in controls $(p<0.02)$. In the remaining DR antigens no differences were found between the two groups. The relative risk for those patients demonstrating DR3 or DR7 was 4.05 and 4.82 respectively. In the group of patients with transitory gluten intolerance $(n=16)$ DR3 was significantly more frequent $(p<0.01)$, but not DR7 compared with controls (table 2). In the two groups of patients with coeliac disease and transitory gluten intolerance the frequency of DR3 was comparable: $60 \% \vee 75 \%$, but DR7 was significantly less frequent in those with transitory gluten intolerance $(p<0.05)$ (table 3$)$. Phenotype distribution in patients with coeliac disease, those with transitory gluten intolerance and controls (taken from Méarin et $a l^{9}$ ) showed that patients with coeliac disease demonstrated a significantly higher distribution of DR3/DR7 $\quad(p<0.01)$ and DR5/DR7 $(\mathrm{p}<0.05)$ phenotype compared with the healthy controls. Patients with transitory gluten intolerance, showed also a higher distribution of DR3/DR7 phenotype compared with controls but surprisingly never DR5/DR7. This difference was significantly different $(p<0.05)$ from patients with coeliac disease (table 3 ). All other phenotype distributions tested were no different from the controls, nor did they show any differences between the two patient groups. Compared with known populations of controls and patients with coeliac disease ${ }^{20}$ in Norway, Spain, Argentina, Italy, and in our own study population the frequency of HLA-DR

Blood samples were subjected to HLA typing by standard lymphocytotoxicity techniques

Table $3 H L A-D R$ phenotype distribution in coeliac disease, transitory gluten intolerance, and controls

\begin{tabular}{|c|c|c|c|c|c|c|c|}
\hline \multirow[b]{2}{*}{$H L A-D R$ phenotype } & \multirow{2}{*}{$\begin{array}{l}\text { No (\%) } \\
\text { controls } \\
(n=76)\end{array}$} & \multicolumn{3}{|c|}{ Coeliac patients } & \multicolumn{3}{|c|}{ Transitory gluten intolerance } \\
\hline & & $\begin{array}{l}\text { No (\%) } \\
(n=45)\end{array}$ & $\begin{array}{l}\text { Significance } \\
\text { (p values) } t\end{array}$ & $\begin{array}{l}\text { Relative } \\
\text { risk } \neq\end{array}$ & $\begin{array}{l}\text { No }(\%) \\
(n=16)\end{array}$ & $\begin{array}{l}\text { Significance } \\
\text { (p values) } t\end{array}$ & $\begin{array}{l}\text { Relative } \\
\text { risk } \neq\end{array}$ \\
\hline $\begin{array}{l}\text { DR1/undetermined } \\
\text { DR2/DR5+DR11 } \\
\text { DR3/DR7 } \\
\text { DR3/other } \\
\text { DR5/undetermined } \\
\text { DR5/DR7 } \\
\text { DR5/other } \\
\text { DR7/undetermined } \\
\text { DR7/other } \\
\text { Other/other }\end{array}$ & $\begin{array}{l}0 \\
4(5 \cdot 3) \\
2(2 \cdot 6) \\
7(9 \cdot 2) \\
1(1 \cdot 3) \\
4(5 \cdot 3) \\
13(17 \cdot 1) \\
4(5 \cdot 3) \\
19(25 \cdot 0) \\
22(29 \cdot 0)\end{array}$ & $\begin{array}{c}2(4 \cdot 4) \\
3(6 \cdot 7) \\
11(24 \cdot 4) \\
11(24 \cdot 4) \\
0 \\
12(26 \cdot 7) \\
3(6 \cdot 7) \\
0 \\
3(6 \cdot 7) \\
13(28 \cdot 8)\end{array}$ & $\begin{array}{l}\text { NS } \\
\text { NS } \\
<0.01 \\
\text { NS } \\
\text { NS } \\
<0.02 \\
\text { NS } \\
\text { NS } \\
\text { NS } \\
<0.01\end{array}$ & $\begin{array}{l}8 \cdot 8 \\
1 \cdot 3 \\
9 \cdot 9 \\
3 \cdot 1 \\
0 \cdot 6 \\
6 \cdot 0 \\
0 \cdot 4 \\
0 \cdot 2 \\
0 \cdot 2 \\
0 \cdot 03\end{array}$ & $\begin{array}{l}2(12 \cdot 5) \\
3(18 \cdot 8) \\
2(12 \cdot 5) \\
5(31 \cdot 3) \\
0 \\
0 \\
2(12 \cdot 5) \\
0 \\
2(12 \cdot 5) \\
0\end{array}$ & $\begin{array}{l}\text { NS } \\
\text { NS } \\
\text { NS } \\
\text { NS } \\
\text { NS } \\
0 \cdot 0165 \\
\text { NS } \\
\text { NS } \\
\text { NS } \\
\text { NS }\end{array}$ & $\begin{array}{r}26 \cdot 4 \\
4 \cdot 2 \\
5 \cdot 1 \\
4 \cdot 4 \\
1 \cdot 5 \\
0 \cdot 5 \\
0 \cdot 8 \\
0 \cdot 5 \\
0 \cdot 5 \\
0 \cdot 07\end{array}$ \\
\hline
\end{tabular}

NS = not significant. Undetermined =no other DR antigen detected (=probable DR homozygous).

${ }^{\star}$ Taken from Mearin et al. ${ }^{9}$ Own Swiss DR phenotypes were not determined.

$\dagger$ Two tailed $p$ value corrected for the number of comparisons, calculated according to Fisher's $\chi^{2}$ test with Yates's correction ¥According to Woolf, with Haldane's continuity correction. 
phenotypes DR3/X and DR5/5 was comparable in both but lowest for DR3/X. The patients with transitory gluten intolerance in our study group, however, showed lower DR3/X and no DR5/7 phenotypes.

\section{Discussion}

The definition of the permanence of coeliac disease has undergone some modifications and changes over the last 25 years. The first ESPGAN criteria of 1969 , proposed at the Interlaken meeting, defined coeliac disease as (a) a structurally abnormal mucosa when taking a diet containing gluten, (b) clear improvement of villous structure when taking a gluten-free diet, and (c) deterioration of the mucosa during challenge. ${ }^{14}$ The revision of these criteria in 1990 stated that the diagnosis of coeliac disease does not require further confirmation if the initial diagnosis is based firstly on the appearance of flat small intestinal mucosa with the histological features of hyperplastic villous atrophy and, secondly, on unequivocal and full clinical remission after withdrawal of gluten from the diet. ${ }^{21}$ Exceptions to this rule are patients in whom the initial diagnosis was established before the age of 2 years and teenagers who tend to abandon the diet. In our study all patients have been challenged with gluten in a prospective manner regardless of the age of onset of coeliac disease. Sixteen subjects out of 61 did not react to gluten challenge and followed a normal diet afterwards for 5-15 years. They were considered to have suffered from transitory gluten intolerance. The number of patients with transitory gluten intolerance was thought to be not unusual because of the large number of proved coeliac patients $(n>450)$ in the hospital. Genetic similarities with coeliac disease or normal controls would be of great help to classify them into either group, because the HLA-DQ genes of patients with coeliac disease are identical to those found among healthy subjects. ${ }^{22}$ In studies in northern Europe close associations have been described with HLA class II alleles such as DR3 and DQ2 (DQA1*0501, DQB1*0201) that are found in $95 \%$ of coeliac patients from these regions. ${ }^{12}$ In southern Europe, where the frequency of DR3 is lower among the control population, HLA class II associations are found significantly with DR3 and DR7. ${ }^{23}$ The DR7 allele in these patients with coeliac disease is found in a heterozygous combination with either DR3 or DR5 alleles. Haplotype examinations show that the DR7 allele appears to be in linkage disequilibrium with the DQ alleles $\mathrm{DQA}^{\star}{ }^{*} 0201 \mathrm{DQB} 1{ }^{\star} 0201$, while the DR5 allele is found with the $D Q$ alleles $\mathrm{DQA1} 0501 \mathrm{DQB1}{ }^{\star} 0301$. Individuals with the heterozygous combination of DR5/7 therefore carry the same combination of $D Q$ alleles (DQA $1{ }^{\star} 0501$ DQB1*0201) as individuals positive for $\mathrm{DR} 3 / \mathrm{X}$. These $\mathrm{DQ}$ alleles are strongly associated with susceptibility of coeliac disease ${ }^{20}$ and are expressed either in cis or transconfiguration suggesting that these molecules are responsible for the specific gliadin binding and thereby present the 'toxic' gliadin peptide to antigen specific $T$ cells. In our group of patients, permanent coeliac disease was associated with DR3/X in $48.8 \%$ and DR5/7 in $26.7 \%$. The DR5/7 association is dependent upon the geographic region and it was shown to have a frequency in our patients similar to southern Europe: $26 \cdot 7 \%$ compared with $28 \%$ in Italy. ${ }^{24}$ The frequency of DR5/7 is highest in Italy and lowest in Norway, probably due to the high frequency of the DR5 allele (49\% in Italy, $13 \%$ in Norway, and $29 \%$ in Spain). The DR3/X frequency of $48.8 \%$ in our group of coeliac patients was lowest compared with other regions in Europe (Norway 95\%, Spain $71 \%$, Argentina $64 \%$, Italy $60 \%$ ), 18 24-26 but was still significantly higher than in all control groups in various regions of Europe (Norway 27\%, Spain 17\%, Argentina 15\%, Italy $16 \%$ ). In the group of patients with transitory gluten intolerance, DR3/X frequency of $43.8 \%$ was lower than in patients with coeliac disease regardless of geographic origin but considerably higher than in healthy controls in Italy. ${ }^{24}$ As the DR alleles in our group of coeliac patients resemble those of the southern Europe group, transitory gluten intolerance might be thought to be associated with the southern European type of DR alleles. It is noticeable that our group of patients with transitory gluten intolerance carries more than twice the percentage of DR3/X alleles than that of controls from Italy. The striking difference from patients with coeliac disease or controls is shown by the absence of DR5/7 alleles. Despite the small patient numbers this might be relevant, because among the 16 patients with transitory gluten intolerance around $8 \%$ (or one patient) should have been found with the DR5/7 phenotype. Further analysis of similarly well defined cases might show whether genetic differences in the DR3/X and DR5/7 phenotypes can serve as a marker for transitory gluten intolerance.

1 Gee S. On the coeliac affection. St Bartholomew's Hospital Reports (London) 1888; 24: 17-20.

2 Dicke WK, Weijers $\mathrm{H}$, van de Kamer J. The presence in wheat of a factor having deleteriuus effect in cases of coeliac disease. Acta Paediatr 1953; 42: 34-42.

3 Selby WS, Janossy G, Bofill M, Jewell DP. Lymphocyte subpopulation in the human small intestine. The finding in normal mucosa and in the mucosa of patients with adult coeliac disease. Clin Exp Immunol 1983; 52: 219-28.

4 Stokes PL, Holmes GKT, Asquith P, Mackintosh P, Cooke WT. Histocompatibility antigens associated with adult coeliac disease. Lancet 1972; ii: 162-4.

5 Tosi R, Vismara D, Tanigaki N, et al. Evidence that coeliac disease is primarily associated with a DC locus allelic

6 Falchuk ZM, Rogentine N, Strober W. Predominance of histocompatibility antigen HL-A8 in patients with gluten histocompatibility antigen HL-A8 in patients with gluten
sensitive enteropathy. $\mathcal{F}$ Clin Invest 1972; 52: 1609-16.

7 Granditsch G, Ludwig H, Polymenidis Z, Wick G. Coeliac disease and HLA-A8. Lancet 1973; ii: 908.

8 DeMarchi M, Borelli I, Olivetti E, et al. Two HLA-D and $\mathrm{DR}$ alleles are associated with coeliac disease. Tissue Antigens 1979; 14: 309-16.

9 Mearin ML, Biemond I, Pena AS, et al. HLA-DR phenotypes in spanish coeliac children: their contribution to the understanding of genetics of the disease. Gut 1983; 24: 532-7.

10 Mearin ML, Bouquet J, Mourad N, et al. HLA-DR antigen and phenotypes in Dutch children and their families. Clin Genet 1985; 27: 45-50.

11 Albert E, Harms K, Bertele R, et al. B-cell alloantigens in coeliac disease. In: McNicholl B, McCarthy CF, Fotrel PF, eds. Perspectives in coeliac disease. Lancaster: MTP Press, 1978: 123-9.

12 Sollid LM, Markussen G, Ek J, Gjerde H, Vartdul F, Thorsby E. Evidence for a primary association of coeliac disease to a particular HLA-DQ alpha/beta heterodimer. f Exp Med 1989; 169: 345-50. 
13 Lundin KEA, Scott H, Hansen T, et al. Gliadin-specific HLA-DQ $\left(\alpha 1^{\star} 0501, \beta 1^{\star} 0201\right)$ restricted T cells isolated from the small intestinal mucosa of coeliac disease patients. F Exp Med 1993; 178: 187-96.

14 Weiters HA, Lindquist B, Anderson CM, et al. Diagnostic criteria in coeliac disease. Acta Paediatr Scand 1970; 59: 461-3.

15 McNeish AS, Rolles CJ, Arthur LJH. Criteria for diagnosis of temporary gluten intolerance. Arch Dis Child 1976; 51: 275-8.

16 Stern M, Fisher K, Grüttner R. Immunofluorescent serum gliadin antibodies in children with coeliac disease and various malabsorptive disorders. Eur $\mathcal{f}$ Pediatr 1979; 130: 155-64.

17 Bürgin-Wolff A, Berger R, Gaze H, Huber H, Lentze MJ, Nüsslé D. IgG, IgA and IgE gliadin antibody determinations as screening test for untreated coeliac disease in children, a

18 Méarin ML, Koninckx CR, Biemond I, Polanco I, Pena AS. Influence of genetic factors on the serum levels of antigliadin antibodies in coeliac disease. $\mathcal{F}$ Pediatr Gastroenterol Nutr 1984; 3: 373-7.

19 Bürgin-Wolff A, Gaze H, Hadziselimovic F, et al. for coeliac disease. Arch Dis Child 1991; 66: 941-7.
20 Sollid LM, Thorsby E. The primary association of coeliac disease to a given HLA-DQ $\alpha / \beta$ heterodimer explains the divergent HLA-DR associations observed in various Caucasian populations. Tissue Antigens 1990; 36: 136-7.

21 Walker-Smith JA, Guandalini S, Schmitz J, Shmerling DH, Visakorpi JK. Revised criteria for diagnosis of coeliac disease. Report of working group of ESPGAN. Arch Dis Child 1990; 65: 909-11.

22 Kagnoff MF, Harwood J, Bugawan TL, Erlich HA. Structural analysis of the HLA-DR, $-D Q$, and -DP alleles on the coeliac disease-associated HLA-DR3 (DRw17) haplotype. Proc Natl Acad Sci USA 1989; 86: 6274-8.

23 Tighe MR, Hall MA, Barbado M, Cardi E, Welsh KI, Ciclitera PJ. HLA class II alleles associated with coeliac disease susceptibility in a southern European population. disease susceptibility in a southern
Tissue Antigens 1992; 332: 845-50.

24 Morellini M, Trabace S, Mazzilli MC, et al. A study of HLA class II antigens in an Italian paediatric population with coeliac disease. Dis Markers 1988; 6: 23-8.

25 Spurkland A, Ronningen KS, Leivestad T, Vartdal F, Thorsby E. HLA-DR-DQ haplotype frequencies in a Norwegian population. Transplant Proc 1992; 24: 298-9. 26 Herrera M, Chertkoff L, Palavecino E, et al. Restriction fragment length polymorphism in HLA class II genes of Latin-American caucasian coeliac disease patients. Hum Immunol 1989; 26: 272-80. 